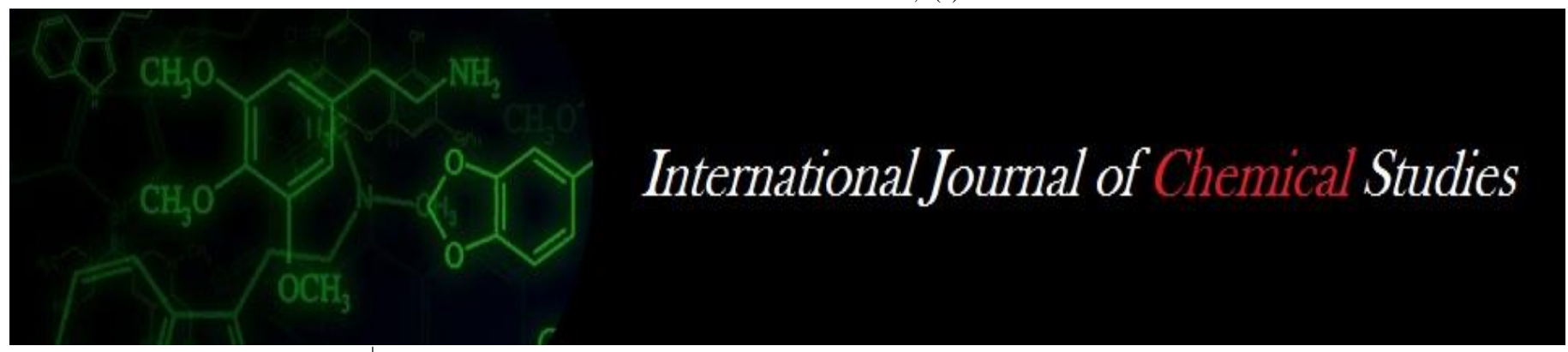

P-ISSN: 2349-8528

E-ISSN: 2321-4902

www.chemijournal.com

IJCS 2020; 8(4): 3995-4001

(C) 2020 IJCS

Received: 14-04-2020

Accepted: 18-05-2020

\section{Sadhana Kongala}

Student, Department of

Vegetable Science, College of

Horticulture, Sri Konda Laxman

Telangana State Horticultural

University, Rajendranagar,

Hyderabad, Telangana, India

\section{Venkateswara Reddy}

Associate Professor, Department

of Horticulture, College of

Agriculture, Professor

Jayashankar Telangana State

Agricultural University,

Rajendranagar, Hyderabad,

Telangana, India

\section{Veena Joshi}

Associate Professor, Fruit

Science, College of Horticulture,

Sri Konda Laxman Telangana

State Horticultural University,

Mojerla, Wanaparty, Telangana,

India

\section{Madhavi MOLLURU}

Principal Scientist and head,

Department of Agronomy,

AICRP on Weed Management,

Professor Jayashankar

Telangana State Agricultural

University, Rajendranagar,

Hyderabad, Telangana, India

\section{Ram Prakash}

Principal Scientist, Department of Soil Science, AICRP on Weed

Management, Professor

Jayashankar Telangana State

Agricultural University,

Rajendranagar, Hyderabad,

Telangana, India

\section{Effect of weed management practices on growth and yield of $k$ harif okra (Abelmoschus esculentus (L.) Moench)}

\author{
Sadhana Kongala, Venkateswara Reddy, Veena Joshi, Madhavi Molluru \\ and Ram Prakash
}

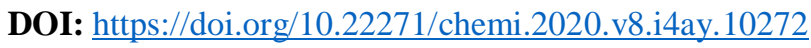

\begin{abstract}
A field experiment was conducted to study the response of kharif okra for different weed management practices at PG research block, College of Horticulture, (Sri Konda Laxman Telangana State Horticultural University) SKLTSHU, Rajendranagar, Hyderabad during the year 2019-20. The experiment was laid out in randomized block design with twelve treatments and replicated thrice. The weed management practices have significantly influenced the growth and yield contributing characters in kharif okra. Among the different weed management practices, black polythene sheet recorded the higher values for growth parameters such as plant height, leaf area, crop dry weight, no of branches, more no of nodes on main stem, pod yield per plant (345.2 g) and total pod yield (15.20 t ha-1) when compared to other treatments. This was on par with mechanical weeding (inter row) followed by hand weeding (intra row) at 30 and 60 DAS (weed free check). The lowest values for growth and yield contributing were recorded with unweeded control plot. This study suggests that growing of okra under black polythene mulch gives higher yield.
\end{abstract}

Keywords: Okra, black polythene mulch, plant growth parameters, yield

\section{Introduction}

Okra [Abelmoschus esculentus (L.) Moench] originated in Africa, belongs to the family Malvaceae, known as Lady's finger, having diploid chromosome no. $2 \mathrm{n}=$

130. Okra is one of the most important vegetables grown in tropical, sub tropical and warm temperate regions of the world. High iodine content of fruit helps control goitre while leaves are to inflamation and dysentery. Okra is one of the most nutritious vegetables which contains on an average of $1.9 \mathrm{~g}$ of protein, $0.2 \mathrm{~g}$ fat, $6.4 \mathrm{~g}$ carbohydrates, $0.7 \mathrm{~g}$ minerals, $1.2 \mathrm{~g}$ fiber per $100 \mathrm{~g}$ of edible portion (Gopalan et al. 1989). At present okra has good potential as a foreign exchange crop and accounts for 60 percent of the export of fresh vegetables. India is the largest producer of okra with an area of 513000 ha and production of 6,170 thousand tonnes with the productivity of $12.0 \mathrm{mt}$ ha-1. In India, UP, Bihar and Orissa are major okra growing states. In Telangana, okra is grown in an area of 12,167 hectares, with production of 1,67,255 tonnes (NHB 2018-19). The crop can't tolerate weed competition due to its slow initial rate of growth and canopy coverage for effective shading. Weeds take advantage of moisture, soil fertility and environmental conditions to suppress the growth of crops. Weeds harbour for pests and diseases causing organisms, cause adverse allelopathic effects on okra and reduce the yield and quality of the produce. Due to this weed competition, the crop remains weak and unhealthy. Due to poor weed management practices in okra, yield losses varied from 40 - 80 percent (Sah et al. 2018) ${ }^{[23]}$. With this background, the present investigation was initiated to study the effect different weed management practices on growth and yield of kharif okra.

\section{Materials and Methods}

The present investigation was carried out at the PG research block of the department of Vegetable science, College of Horticulture, Rajendranagar, during Kharif - 2019. The experiment was laid out in Randomized block design with twelve treatments and replicated thrice.

\footnotetext{
Corresponding Author: Sadhana Kongala

Student, Department of
Vegetable Science, College of Horticulture, Sri Konda Laxman Telangana State Horticultural University, Rajendranagar, Hyderabad, Telangana, India
} 
The soil was sandy loam in texture, having $0.57 \%$ organic carbon, low in available nitrogen (192 kg ha-1), phosphorus (5 kg ha-1) and potassium (272 kg ha-1) and slightly acidic reaction $(\mathrm{pH} 7.51)$, with normal electrical conductivity $(0.22$ dsm-1). Twelve weed control treatments consisting of oxyfluorfen $0.2 \mathrm{~kg}$ ha-1 (PE) + propaquizafop $62.5 \mathrm{~g}$ ha-1 $(\mathrm{PoE})+$ intercultivation at 45 DAS (T1), pendimethalin $675 \mathrm{~g}$ ha-1 (PE) + propaquizafop $62.5 \mathrm{~g}$ ha-1 (PoE) + intercultivation at 45 DAS (T2), oxadiargyl $90 \mathrm{~g}$ ha-1 (PE) + propaquizafop $62.5 \mathrm{~g}$ ha-1 $(\mathrm{PoE})+$ intercultivation at $45 \mathrm{DAS}$ (T3), oxyfluorfen $0.2 \mathrm{~kg}$ ha-1 $(\mathrm{PE})+$ rice straw mulch at 7-10 DAS (T4), pendimethalin $675 \mathrm{~g}$ ha-1 + rice straw mulch at 7 10 DAS (T5), oxadiargyl $90 \mathrm{~g}$ ha-1 + rice straw mulch at 7-10 DAS (T6), rice straw mulch at 7-10 DAS (T7), black polythene mulch (T8), stale seed bed + intercropping with green leafy vegetable (palak) (T9), mechanical weeding at 15 , 30, 60 DAS (T10), mechanical weeding (inter row) followed by hand weeding (intra row) - (weed free check) (T11), unweeded control (T12). The seed of okra cv arka anamika was sown at $60 \times 30 \mathrm{~cm}$ spacing. The field was fertilized with farm yard manure at the rate $25 \mathrm{t}$ ha- 1 at the time of last ploughing and incorporated well into the soil. Ridges and furrows were formed at a spacing of $60 \mathrm{~cm}$. The recommended basal dose of fertilizer at the rate of $40 \mathrm{~kg}$ ha- 1 nitrogen, $60 \mathrm{~kg}$ ha- 1 of phosphorus and $60 \mathrm{~kg}$ ha- 1 of potash was applied in the form of urea, single super phosphate and muriate of potash respectively and mixed with soil. Immediately after fertilizer application irrigation was provided. Thirty days after sowing, $40 \mathrm{~kg}$ of nitrogen per hectare was applied as top dressing and remaining $40 \mathrm{~kg}$ per hectare is applied at sixty days after sowing. Crop was sown on 23rd july 2019. Data were recorded on plant height, leaf area, crop dry weight, no of branches, no of nodes on main stem, days to initial flowering, days to $50 \%$ flowering, pod yield per plant and total pod yield by selecting five plants excluding border plants. Leaf area was computed at 30, 60, 90 DAS by using LI-COR LT-3000 portable leaf area meter with transparent belt conveyor with an electronic digital display and is expressed in $\mathrm{cm} 2$. Total yield was calculated by adding total of 5 pickings at four days interval till final harvesting after 45 days after sowing.

\section{Results and discussion Plant height $(\mathbf{c m})$}

The effect of black polythene sheet on plant height was recorded in different stages i.e. 30, 60 and 90 DAS are presented in Table 1. The plant height increased with the advancement in crop age, irrespective of the treatment and reached maximum at harvest. The rate of increase in plant height was more at 30 to 60 DAS as compared to 60 DAS to harvest stage. At all the stages application of black polythene mulch sheet recorded the highest plant height and it was on par with mechanical weeding (inter row) followed by hand weeding (intra row) at 30 and 60 DAS (weed free check). The lowest plant height was recorded in unweeded control. Mulching with black polythene sheet recorded the highest plant height throughout the crop growth period. This may be due to better moisture conservation for plants under the mulch than hand weeding. It may also be attributed to better weed control as reported by Ritesh et al. (2018) ${ }^{[22]}$. Unweeded control plots recorded the lowest plant height throughout the crop period. Higher moisture stress resulting from transpiration on the weedy plots and especially the above and underground competitions from weeds may be responsible for poor height in unweeded plot. These results are similar to the results of Suresh et al. (2014) ${ }^{[27]}$, Dalorima et al. (2014) ${ }^{[5]}$,
Bhutia et al. (2017) ${ }^{[4]}$, Manju et al. (2017) ${ }^{[16]}$, Ritesh et al. $(2018)^{[22]}$, Shivaraj et al. (2018) ${ }^{[26]}$, Laxmikanth et al. (2018) ${ }^{[14]}$, Ashish et al. (2018) ${ }^{[1]}$ and Nagegowda et al. (2019) ${ }^{[17]}$.

\section{Leaf area $(\mathrm{cm} 2)$}

Statistically analyzed data pertaining to leaf area at different stages of crop growth is presented in Table 1. The leaf area increased from emergence and reached its peak at crop maturity. At all the three intervals, significantly the maximum leaf area was recorded in black polythene mulch it was on par with mechanical weeding (inter row) followed by hand weeding (intra row) at 30 and 60 DAS (weed free check). The minimum leaf area was recorded in unweeded control. These results were in line and agreement with the findings by Konyeha et al. (2013) ${ }^{[11]}$. Leaf abscission was observed to be greater on unweeded control. This could be attributed to the adverse effect of competition between okra plants and weeds. Okra plant could not absorb enough moisture and nutrient to sustain the leaves because moisture availability plays an important role in better nutrient uptake, higher photosynthetic efficiency which in turn results in better leaf size growth. Bagudo et al. (2016) [2], Shivaraj et al. (2018) ${ }^{[26]}$ and Nagegowda et al. $(2019)^{[17]}$.

\section{Dry matter production of crop (g m-2)}

Weed management practices significantly influenced dry matter production of crop and the data recorded regarding dry matter production of crop at 30,60, 90 DAS was given in Table 1 and Fig 1. At 30,60 and 90 DAS, significantly the maximum dry matter accumulation was recorded in black polythene sheet and it was followed by mechanical weeding (inter row) followed by hand weeding (intra row) at 30 and 60 DAS (weed free check). The minimum dry matter accumulation was recorded in unweeded control. This might be due to soil moisture conservation was observed under black polythene sheet. The improvement in growth characters as a result of using mulches might be due to the enhancement in photosynthesis and other metabolic activities (Bhatt et al. 2011 and Parmar et al. 2013) ${ }^{[3,20]}$. Mulches benefit the plant growth by conserving soil structure and acting as a barrier to the rainfall which causes soil compaction and soil erosion. Less-compacted soil provides a better environment for seedling emergence and root growth (Kumar \& Dey, 2011) ${ }^{[12]}$. The better root growth is also because plastic mulch creates a salt free zone around the plant root system, encouraging better growth, which has positively reflected on vegetative and yield parameters. Similar findings were also reported by Gordon et al. (2010) ${ }^{[7]}$, Hamid et al. (2012) ${ }^{[8],}$ Ogbomo et al. (2013) ${ }^{[13]}$, Bhutia et al. (2017) ${ }^{[4]}$ and Patel et al. $(2017)^{[21]}$.

\section{Number of branches per plant}

The statistically analyzed data regarding no of branches is presented in Table At 30 DAS, branches were not found but at 60 DAS, the highest no of branches were recorded in black polythene sheet mulch and it was on par with mechanical weeding (inter row) followed by hand weeding (intra row) at 30 and 60 DAS (weed free check). The lowest no of branches were recorded in unweeded control. In general, the number of branches increased from 30 DAS to 90 DAS. Higher number of branches under black polythene might be due to better moisture conservation for plants under the mulch than hand weeding. Conversely, the lowest number of branches were noticed in unweeded control. Severe infestation of weeds might have reduced the vegetative growth of plants. Higher 
moisture stress resulting from transpiration on the weedy plots and especially the above and underground competitions from weeds may be responsible for poor okra growth on all the time weedy plot. These results were similar to Suresh et al. (2014) ${ }^{[27]}$, Dalorima et al. (2014) ${ }^{[5]}$, Bhutia et al. (2017) ${ }^{[4]}$, Manju et al. (2017) ${ }^{[16]}$, Shivaraj et al. (2018) ${ }^{[26]}$, Laxmikanth et al. (2018) ${ }^{[14]}$, Ashish et al. (2018) ${ }^{[1]}$ and Nagegowda et al. $(2019)^{[17]}$.

\section{Number of nodes on main stem per plant}

No of nodes were significantly influenced by various weed control practices and the data pertaining to no of nodes at different stages of crop growth is presented in Table 1. At 30, 60 and 90 DAS, significantly the highest no of nodes on main stem were recorded in black polythene sheet mulch it was on par with mechanical weeding (inter row) followed by hand weeding (intra row) at 30 and 60 DAS (weed free check). The lowest no of nodes were recorded in unweeded control. This might be due to better moisture conservation for plants under the mulch than under hand weeding. Unweeded control plots recorded the lowest no of nodes throughout the crop period. Higher moisture stress resulting from transpiration on the weedy plots and especially the above and underground competitions from weeds may be responsible for poor no of nodes in weedy plot. Our findings were supported to Bhutia et al. (2014) ${ }^{[4]}$, Patel et al. (2017) ${ }^{[21]}$ and Shivaraj et al. (2018) [26]

\section{Number of days to initial flowering and $50 \%$ flowering}

The data pertaining to the days taken to initial and $50 \%$ flowering as per visual observations made was presented in Table 2. The data indicated that the crop had taken about 36 days for initial flowering and 39 days for 50 per cent flowering in black polythene sheet mulch which was on par with mechanical weeding (inter row) followed by hand weeding (intra row) at 30 and 60 DAS (weed free check) at 39 and 41 DAS respectively. Initial and $50 \%$ flowering was delayed in unweeded control 48 and 52 DAS respectively. The earliness in crop maturity under black polythene, might be related with the increased accumulated soil temperature under polythene film mulch. The earliness in flowering can also be attributed to simultaneous transport of growth substances like cytokinin to the auxillary bud breaking the apical dominance. Hazarika and Ansari, $2010^{[9]}$, Ogbomo et al. (2013) ${ }^{[13]}$ and Nagegowda et al. (2019) ${ }^{[17]}$.

\section{Pod characters}

The data pertaining to the pod characters (pod length, diameter and weight) were presented in Table 2. Significantly maximum pod length, diameter and weight were recorded in black polythene sheet mulch treatment which was on par with mechanical weeding (inter row) followed by hand weeding (intra row) at 30 and 60 DAS (weed free check). The minimum pod length was recorded in unweeded control. Black plastic mulch enhanced better plant growth, which facilitated in accumulation of more photosynthates and conservation of optimum temperature resulting in increased size and weight of fruits. Similar results were found by Shivaraj et al. (2018) ${ }^{[26]}$. Growth is the function of photosynthetic activity of the okra plant and their capacity to utilize available nutrients. Thus enhanced availability of nutrients, water, light and space resulted in increase in plant height, number of leaves and dry matter accumulation which reflected in term of higher pod length, pod diameter and average pod weight. These findings were supported by Pandey and Mishra (2013) ${ }^{[19]}$, Ogbomo et al. (2013) ${ }^{[13]}$, Shivalingappa et al. (2014) ${ }^{[25]}$, Jalendhar et al. (2016) and Patel et al. $(2017)^{[21]}$.

\section{Pod yield}

Pod yield contributing characters like number of pods per plant, pod yield per plant and total pod yield were significantly influenced by various weed management practices and the data is given in Table 2 .

\section{Number of Pods per plant}

Highest number of pods per plant recorded with black polythene sheet mulch (23.81) it was on par with mechanical weeding (inter row) followed by hand weeding (intra row) at 30 and 60 DAS (weed free check) (22.89). The minimum number of pods per plant recorded in unweeded control (7.89). Similar results were reported by Suresh et al. (2014) ${ }^{[27]}$, Dalorima et al. (2014) ${ }^{[5]}$, Bhutia et al. (2017) ${ }^{[4]}$, Shivaraj et al. (2018) [26], Laxmikanth et al. (2018) ${ }^{[14], ~ A s h i s h ~ e t ~ a l . ~}$ (2018) ${ }^{[1]}$ and Nagegowda et al. (2019) ${ }^{[17]}$.

\section{Pod yield per plant (g plant-1)}

Pod yield per plant was significantly highest in black polythene sheet mulch treatment (345.2) which was followed by mechanical weeding (inter row) followed by hand weeding (intra row) at 30 and 60 DAS (weed free check) (298.3). The least pod yield per plant was recorded in unweeded control (83.5).

\section{Total pod yield (t ha-1)}

Maximum pod yield was recorded in black polythene sheet mulch treatment (15.20) which was on par with mechanical weeding (inter row) followed by hand weeding (intra row) at 30 and 60 DAS (weed free check) (14.93). The least total pod yield was recorded in unweeded control (4.09). Higher yield of okra obtained with the black polythene mulching, might be due to direct effect of improved soil nutrients, structure and moisture content and reduced weed pressure. The solarization effect of plastic mulch makes for higher nutrient availability results in higher yields. Mahadeen (2014) also have reported positive effect of black polythene sheet mulching on yield of okra. Reduced pod yield in case of unweeded control might be due to reduced plant growth, reduced fruit size and number and due to severe crop weed competition for nutrients, moisture, light and space during the crop growth period. Similar results were reported by Sathya et al. (2013) ${ }^{[24]}$, Jalendhar et al. (2016) ${ }^{[10]}$, Bhutia et al. (2017) ${ }^{[4]}$, Ritesh et al. (2018) ${ }^{[22]}$ and Nagegowda et al. (2019) ${ }^{[17]}$. 
Table 1: Influence of weed management practices $(\mathrm{cm})$, Leaf area $(\mathrm{cm} 2)$, dry matter production $(\mathrm{g} \mathrm{m}-2)$, no of branches and no of nodes per main stem

\begin{tabular}{|c|c|c|c|c|c|c|c|c|c|c|c|c|c|c|c|c|}
\hline \multirow{2}{*}{\multicolumn{2}{|c|}{ Treatment }} & \multicolumn{3}{|c|}{ Plant height (cm) } & \multicolumn{3}{|c|}{ Leaf area $(\mathrm{cm} 2)$} & \multicolumn{3}{|c|}{\begin{tabular}{|c|} 
Dry matter production $(\mathrm{g}$ \\
$\mathrm{m} 2)$
\end{tabular}} & \multicolumn{3}{|c|}{ No of branches } & \multicolumn{3}{|c|}{ No of nodes per main stem } \\
\hline & & \multicolumn{2}{|c|}{\begin{tabular}{|l|l|l|l|l|l} 
30 DAS & 60 DAS \\
\end{tabular}} & \multirow{2}{*}{\begin{tabular}{|l|} 
90 DAS \\
$97.01 \mathrm{~cd}$
\end{tabular}} & \multirow{2}{*}{\begin{tabular}{|l|} 
30 DAS \\
$21.83 \mathrm{gh}$
\end{tabular}} & \multirow{2}{*}{$\begin{array}{l}\text { 60 DAS } \\
91.67 \mathrm{~g}\end{array}$} & \multirow{2}{*}{\begin{tabular}{|l|} 
90 DAS \\
$941.65 \mathrm{e}$ \\
\end{tabular}} & \multirow{2}{*}{\begin{tabular}{|c|} 
30 DAS \\
$6.95 \mathrm{~d}$ \\
\end{tabular}} & \multirow{2}{*}{\begin{tabular}{|l|} 
60 DAS \\
$205.30 \mathrm{c}$ \\
\end{tabular}} & \multirow{2}{*}{$\begin{array}{l}\text { 90 DAS } \\
320.10 \mathrm{f}\end{array}$} & \multirow{2}{*}{\begin{tabular}{|c|} 
30 DAS \\
$1.43 \mathrm{ef}$ \\
\end{tabular}} & \multirow{2}{*}{\begin{tabular}{|l|} 
60 DAS \\
$3.22 \mathrm{~cd}$ \\
\end{tabular}} & \multirow{2}{*}{\begin{tabular}{|l|} 
90 DAS \\
$1.43 \mathrm{ef}$ \\
\end{tabular}} & \multirow{2}{*}{$\begin{array}{l}\text { 30 DAS } \\
2.80 \mathrm{de}\end{array}$} & \multirow{2}{*}{\begin{tabular}{|l|} 
60 DAS \\
$6.07 \mathrm{de}$
\end{tabular}} & \multirow{2}{*}{\begin{tabular}{r|} 
90 DAS \\
$14.00 \mathrm{~d}$
\end{tabular}} \\
\hline $\mathrm{T} 1$ & $\begin{array}{c}\text { Oxyfluorfen } 23.5 \% \text { EC } 0.2 \mathrm{~kg} \text { ha-1 (PE) } f b \\
\text { propaquizafop } 10 \% \text { EC } 62.5 \mathrm{~g} \text { ha- } 1 \text { at } 2-3 \text { leaf stage } \\
\text { (PoE) } f b \text { intercultivation at } 45 \text { DAS. }\end{array}$ & $17.15 \mathrm{c}$ & $59.95 \mathrm{e}$ & & & & & & & & & & & & & \\
\hline $\mathrm{T} 2$ & $\begin{array}{l}\text { Pendimethalin } 38.7 \% \text { CS } 675 \mathrm{~g} \text { ha- } 1 \text { (PE) } f b \\
\text { propaquizafop } 10 \% \text { EC } 62.5 \mathrm{~g} \text { ha- } 1 \text { at } 2-3 \text { leaf stage } \\
\text { (PoE) } f b \text { intercultivation at } 45 \text { DAS. }\end{array}$ & $19.78 \mathrm{c}$ & $76.20 \mathrm{c}$ & $111.11 \mathrm{bc}$ & $34.03 f g$ & $177.89 b$ & $1114.63 d$ & $7.55 \mathrm{c}$ & 176.61e & $341.15 \mathrm{~d}$ & $2.40 \mathrm{~cd}$ & $4.22 \mathrm{~b}$ & $2.40 \mathrm{~cd}$ & $3.47 \mathrm{~cd}$ & $8.00 \mathrm{~cd}$ & $14.55 \mathrm{~d}$ \\
\hline $\mathrm{T} 3$ & $\begin{array}{c}\text { Oxadiargyl } 80 \% \text { WP } 90 \mathrm{~g} \text { ha-1 (PE) } f b \\
\text { propaquizafop 10\% EC 62.5 g ha-1 at 2-3 leaf stage } \\
\text { (PoE) } f b \text { intercultivation at } 45 \text { DAS. }\end{array}$ & $18.56 \mathrm{c}$ & $72.81 \mathrm{~cd}$ & $105.58 \mathrm{c}$ & $41.28 \mathrm{e}$ & 129.72ef & $1139.43 d$ & $7.62 \mathrm{c}$ & $189.56 \mathrm{~d}$ & $340.83 d$ & $2.17 \mathrm{~d}$ & $4.99 b$ & $2.17 \mathrm{~d}$ & $3.53 \mathrm{c}$ & $10.13 b$ & $14.00 \mathrm{~d}$ \\
\hline $\mathrm{T} 4$ & $\begin{array}{l}\text { Oxyfluorfen } 23.5 \% \text { EC } 0.2 \mathrm{~kg} \text { ha-1 (PE) followed by } \\
\text { rice straw mulch (5t ha-1) at 7-10 DAS. }\end{array}$ & $16.80 \mathrm{~cd}$ & 62.84de & $119.11 \mathrm{~b}$ & $25.05 \mathrm{~g}$ & $94.53 \mathrm{~g}$ & $1288.11 \mathrm{c}$ & $6.09 \mathrm{e}$ & $186.77 \mathrm{de}$ & $319.66 \mathrm{f}$ & $1.67 \mathrm{e}$ & $4.11 \mathrm{bc}$ & $1.67 \mathrm{e}$ & $4.33 \mathrm{bc}$ & $9.33 b$ & $18.33 \mathrm{bc}$ \\
\hline T5 & $\begin{array}{l}\text { Pendimethalin } 38.7 \% \text { CS } 675 \mathrm{~g} \text { ha- } 1 \mathrm{fb} \text { rice straw } \\
\text { mulch (5t ha-1) at 7-10 DAS. }\end{array}$ & $24.12 b$ & $82.87 \mathrm{~b}$ & $122.08 \mathrm{~b}$ & $53.18 \mathrm{~cd}$ & $144.92 \mathrm{~d}$ & $1467.55 b$ & $6.67 \mathrm{de}$ & $191.54 \mathrm{~d}$ & $333.64 \mathrm{e}$ & $2.67 \mathrm{c}$ & $4.55 \mathrm{~b}$ & $2.67 \mathrm{c}$ & $4.67 \mathrm{~b}$ & $10.40 \mathrm{~b}$ & $17.33 \mathrm{c}$ \\
\hline T6 & $\begin{array}{c}\text { Oxadiargyl } 80 \% \text { WP } 90 \mathrm{~g} \text { ha- } 1 \mathrm{fb} \text { rice straw mulch } \\
(5 \mathrm{t} \text { ha-1) at } 7-10 \text { DAS }\end{array}$ & $23.00 \mathrm{~b}$ & $82.19 \mathrm{bc}$ & $122.40 \mathrm{~b}$ & $48.07 \mathrm{~d}$ & $151.92 \mathrm{~cd}$ & $1444.92 \mathrm{~b}$ & $6.75 \mathrm{~d}$ & $193.19 \mathrm{~d}$ & $343.55 \mathrm{~d}$ & $2.77 \mathrm{c}$ & $4.99 \mathrm{~b}$ & $2.77 \mathrm{c}$ & $4.60 \mathrm{~b}$ & $10.53 \mathrm{~b}$ & $18.77 \mathrm{~b}$ \\
\hline $\mathrm{T} 7$ & Rice straw mulch at 7-10 DAS (5t ha-1). & $23.63 \mathrm{~b}$ & $83.27 \mathrm{~b}$ & $117.81 \mathrm{~b}$ & $52.70 \mathrm{~cd}$ & $146.38 \mathrm{~d}$ & $\mid 1479.38 \mathrm{~b}$ & $7.56 \mathrm{c}$ & $187.47 \mathrm{~d}$ & $402.92 \mathrm{c}$ & $3.60 \mathrm{~b}$ & $4.29 \mathrm{~b}$ & $3.60 \mathrm{~b}$ & $4.40 \mathrm{~b}$ & $10.67 \mathrm{~b}$ & $17.11 \mathrm{c}$ \\
\hline $\mathrm{T} 8$ & Black polythene mulch. & $33.74 a$ & $94.75 \mathrm{a}$ & $131.35 \mathrm{a}$ & 126.90a & $224.74 \mathrm{a}$ & $1549.22 \mathrm{a}$ & $11.94 \mathrm{a}$ & $240.64 \mathrm{a}$ & $545.63 \mathrm{~b}$ & $4.21 \mathrm{a}$ & $6.03 \mathrm{a}$ & $4.21 \mathrm{a}$ & $5.80 \mathrm{a}$ & $12.74 \mathrm{a}$ & $21.55 \mathrm{a}$ \\
\hline T9 & $\begin{array}{l}\text { Stale seed bed followed by inter cropping with green } \\
\text { leafy vegetable (palak). }\end{array}$ & $22.66 \mathrm{bc}$ & $77.75 \mathrm{c}$ & $118.98 b$ & $34.56 \mathrm{f}$ & $163.12 \mathrm{bc}$ & $1166.24 d$ & $7.84 \mathrm{c}$ & $210.60 \mathrm{bc}$ & $405.03 \mathrm{c}$ & $2.67 \mathrm{c}$ & $4.11 \mathrm{bc}$ & $2.67 \mathrm{c}$ & $4.13 \mathrm{c}$ & $9.53 \mathrm{~b}$ & $14.89 \mathrm{~d}$ \\
\hline T10 & Mechanical weeding at $15,30,60$ DAS. & $23.71 \mathrm{~b}$ & $68.66 \mathrm{~d}$ & $119.07 \mathrm{~b}$ & $58.38 \mathrm{c}$ & $126.75 \mathrm{f}$ & $1113.93 \mathrm{~d}$ & $7.30 \mathrm{~cd}$ & $220.88 \mathrm{~b}$ & $401.67 \mathrm{c}$ & $2.53 \mathrm{c}$ & $4.67 \mathrm{~b}$ & $2.53 \mathrm{c}$ & $4.33 \mathrm{~b}$ & $9.07 \mathrm{bc}$ & $14.33 \mathrm{~d}$ \\
\hline T11 & $\begin{array}{c}\text { Mechanical weeding (inter row) followed by hand } \\
\text { weeding (intra row) at } 30 \text { and } 60 \text { DAS - (weed free } \\
\text { check). }\end{array}$ & $30.72 \mathrm{a}$ & $88.76 \mathrm{ab}$ & $125.64 \mathrm{ab}$ & $79.91 \mathrm{~b}$ & $143.99 \mathrm{de}$ & $1495.56 \mathrm{ab}$ & $10.51 \mathrm{~b}$ & $238.65 \mathrm{a}$ & $565.43 \mathrm{a}$ & $4.07 \mathrm{a}$ & $5.29 \mathrm{ab}$ & $4.07 \mathrm{a}$ & $5.30 \mathrm{ab}$ & $10.97 a b$ & $20.00 \mathrm{ab}$ \\
\hline T12 & Unweeded Control & $14.45 \mathrm{~d}$ & $37.93 \mathrm{f}$ & $65.11 \mathrm{~d}$ & $18.73 \mathrm{~h}$ & $90.55 \mathrm{~g}$ & $769.39 \mathrm{f}$ & $4.65 \mathrm{f}$ & $135.58 \mathrm{f}$ & $238.54 \mathrm{~g}$ & $1.12 \mathrm{f}$ & $2.37 \mathrm{~d}$ & $1.12 \mathrm{f}$ & $2.23 \mathrm{e}$ & $5.67 \mathrm{e}$ & $10.55 \mathrm{e}$ \\
\hline & $\mathrm{SE}(\mathrm{m}) \pm$ & 1.03 & 2.26 & 4.09 & 2.14 & 4.84 & 23.34 & 0.21 & 3.80 & 1.65 & 0.13 & 0.31 & 0.13 & 0.35 & 0.67 & 0.67 \\
\hline & CD at $5 \%$ & 3.02 & 6.62 & 12.00 & 6.30 & 14.20 & 68.46 & 0.63 & 11.14 & 4.95 & 0.39 & 0.91 & 0.39 & 1.03 & 1.97 & 1.98 \\
\hline
\end{tabular}

Table 2: Influence of weed management practices on number of days to flowering, pod characters and yield

\begin{tabular}{|c|c|c|c|c|c|c|c|c|c|}
\hline \multicolumn{2}{|r|}{ Treatment } & $\begin{array}{c}\text { Initial } \\
\text { flowering }\end{array}$ & $\begin{array}{c}\mathbf{5 0 \%} \\
\text { flowering }\end{array}$ & $\begin{array}{l}\text { Pod length } \\
\text { (cm) }\end{array}$ & \begin{tabular}{|c|} 
Pod diameter \\
$(\mathrm{cm})$
\end{tabular} & $\begin{array}{c}\text { Pod weight } \\
(\mathrm{g})\end{array}$ & $\begin{array}{l}\text { No. of pods per } \\
\text { plant (no) }\end{array}$ & $\begin{array}{c}\text { Pod yield per } \\
\text { plant (g) }\end{array}$ & $\begin{array}{c}\text { Total Pod yield } \\
\text { (t ha-1) }\end{array}$ \\
\hline $\mathrm{T} 1$ & $\begin{array}{c}\text { Oxyfluorfen 23.5\% EC } 0.2 \mathrm{~kg} \text { ha-1 (PE) } f b \text { propaquizafop } 10 \% \text { EC } 62.5 \mathrm{~g} \text { ha-1 at } 2-3 \\
\text { leaf stage (PoE) } f b \text { intercultivation at } 45 \text { DAS. }\end{array}$ & $44.31 \mathrm{~cd}$ & $49.44 \mathrm{c}$ & $11.24 \mathrm{~b}$ & $1.22 \mathrm{~d}$ & $9.98 \mathrm{c}$ & $9.89 \mathrm{~d}$ & $161.5 \mathrm{de}$ & $5.32 \mathrm{ef}$ \\
\hline $\mathrm{T} 2$ & $\begin{array}{c}\text { Pendimethalin } 38.7 \% \text { CS } 675 \mathrm{~g} \text { ha-1 (PE) } f b \text { propaquizafop } 10 \% \text { EC } 62.5 \mathrm{~g} \text { ha-1 at } 2-3 \\
\text { leaf stage (PoE) } f b \text { intercultivation at } 45 \text { DAS. }\end{array}$ & $41.48 \mathrm{~b}$ & $45.62 \mathrm{~b}$ & $11.71 \mathrm{~b}$ & $1.26 \mathrm{~d}$ & $10.44 \mathrm{~b}$ & $14.22 \mathrm{c}$ & $183.7 \mathrm{~d}$ & $11.29 \mathrm{~b}$ \\
\hline T3 & $\begin{array}{c}\text { Oxadiargyl 80\% WP } 90 \mathrm{~g} \text { ha-1 (PE) } f b \text { propaquizafop 10\% EC } 62.5 \mathrm{~g} \text { ha-1 at 2-3 leaf } \\
\text { stage (PoE) } f b \text { intercultivation at 45 DAS. }\end{array}$ & $41.91 \mathrm{bc}$ & $45.71 b$ & $11.13 b$ & $1.43 \mathrm{c}$ & $10.51 \mathrm{~b}$ & $14.67 \mathrm{c}$ & $187.7 \mathrm{~cd}$ & $10.41 \mathrm{~b}$ \\
\hline $\mathrm{T} 4$ & $\begin{array}{c}\text { Oxyfluorfen } 23.5 \% \text { EC } 0.2 \mathrm{~kg} \text { ha-1 (PE) followed by rice straw mulch (5t ha- } 1 \text { ) at 7-10 } \\
\text { DAS. }\end{array}$ & $47.10 \mathrm{~d}$ & $50.40 \mathrm{c}$ & $10.90 \mathrm{~b}$ & $1.32 \mathrm{~cd}$ & $9.34 \mathrm{c}$ & $10.00 \mathrm{~d}$ & $134.1 \mathrm{e}$ & $5.58 \mathrm{e}$ \\
\hline T6 & Oxadiargyl $80 \%$ WP $90 \mathrm{~g}$ ha- $1 \mathrm{fb}$ rice straw mulch (5t ha-1) at 7-10 DAS & $39.64 \mathrm{~b}$ & $41.90 \mathrm{a}$ & $11.17 \mathrm{~b}$ & $1.27 \mathrm{~d}$ & $10.80 \mathrm{~b}$ & $16.67 \mathrm{~b}$ & $201.7 \mathrm{c}$ & $9.78 \mathrm{c}$ \\
\hline $\mathrm{T} 7$ & Rice straw mulch at 7-10 DAS (5t ha-1). & $39.90 \mathrm{~b}$ & $42.34 \mathrm{ab}$ & $11.44 \mathrm{~b}$ & $1.67 \mathrm{~b}$ & $10.14 \mathrm{c}$ & $18.44 \mathrm{~b}$ & $218.1 \mathrm{c}$ & $11.75 \mathrm{~b}$ \\
\hline $\mathrm{T} 8$ & Black polythene mulch. & $35.67 \mathrm{a}$ & $39.23 \mathrm{a}$ & $12.74 \mathrm{a}$ & $2.58 \mathrm{a}$ & $12.90 \mathrm{a}$ & $23.81 \mathrm{a}$ & $345.2 \mathrm{a}$ & $15.20 \mathrm{a}$ \\
\hline T9 & Stale seed bed followed by inter cropping with green leafy vegetable (palak). & $42.55 \mathrm{c}$ & $44.52 \mathrm{~b}$ & $10.85 \mathrm{bc}$ & $1.35 \mathrm{c}$ & $10.35 \mathrm{~b}$ & $14.77 \mathrm{c}$ & $164.6 \mathrm{~d}$ & $8.22 \mathrm{~d}$ \\
\hline
\end{tabular}




\begin{tabular}{|c|c|c|c|c|c|c|c|c|c|}
\hline T10 & Mechanical weeding at $15,30,60$ DAS. & $43.95 \mathrm{c}$ & $45.74 \mathrm{bc}$ & $10.98 \mathrm{~b}$ & $1.51 \mathrm{c}$ & $10.34 \mathrm{bc}$ & $14.67 \mathrm{c}$ & $176.5 \mathrm{~d}$ & $9.14 \mathrm{~d}$ \\
\hline T11 & $\begin{array}{l}\text { Mechanical weeding (inter row) followed by hand weeding (intra row) at } 30 \text { and } 60 \\
\text { DAS - (weed free check). }\end{array}$ & 38.62ab & $41.13 \mathrm{a}$ & $12.11 \mathrm{ab}$ & $2.32 \mathrm{ab}$ & $11.88 \mathrm{ab}$ & $22.89 \mathrm{a}$ & $298.3 b$ & $14.93 a$ \\
\hline T12 & Unweeded Control & $48.26 \mathrm{~d}$ & $52.09 \mathrm{c}$ & $9.45 c$ & $0.84 \mathrm{e}$ & $7.98 \mathrm{~d}$ & $7.89 \mathrm{e}$ & $83.5 \mathrm{f}$ & $4.09 \mathrm{f}$ \\
\hline & $\mathrm{SE}(\mathrm{m}) \pm$ & 1.31 & 1.41 & 0.40 & 0.13 & 0.56 & 0.61 & 10.58 & 0.50 \\
\hline & $\mathrm{CD}$ at $5 \%$ & 3.84 & 4.12 & 1.16 & 0.37 & 1.64 & 1.79 & 31.04 & 1.46 \\
\hline
\end{tabular}

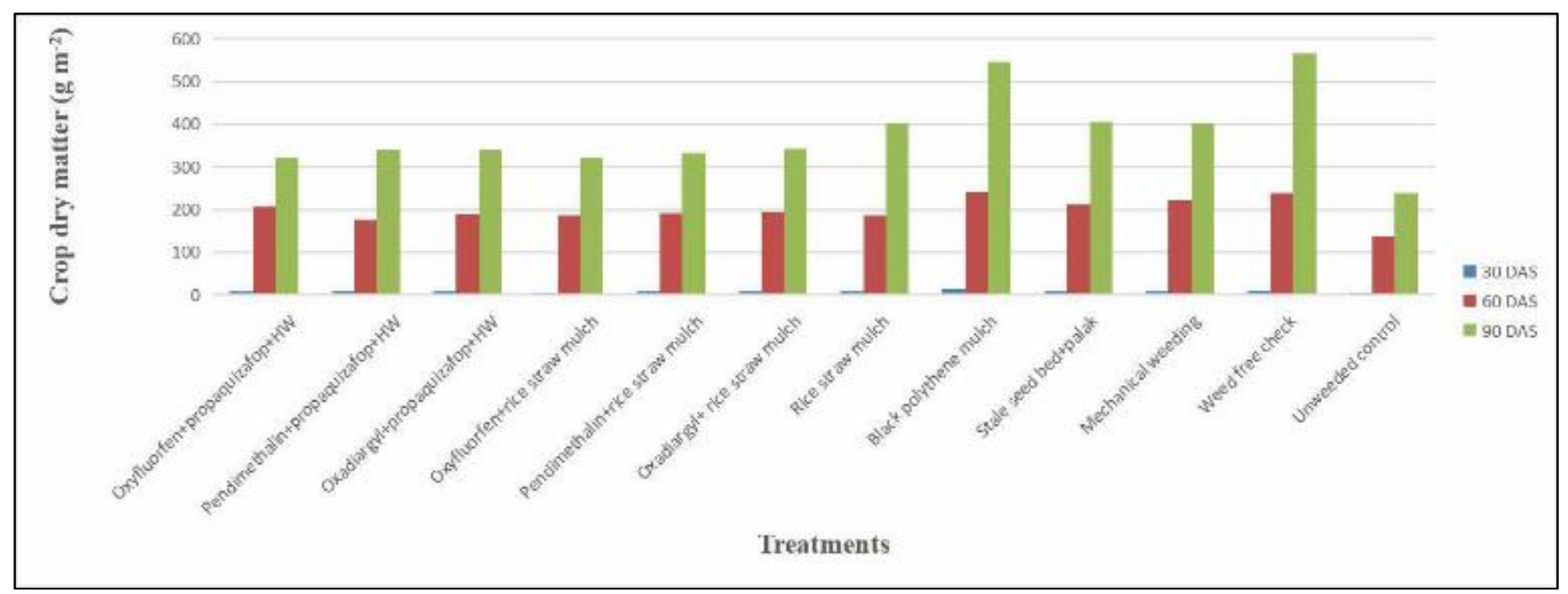

Fig 1: Influence of weed management practices on crop dry matter (g m-2)

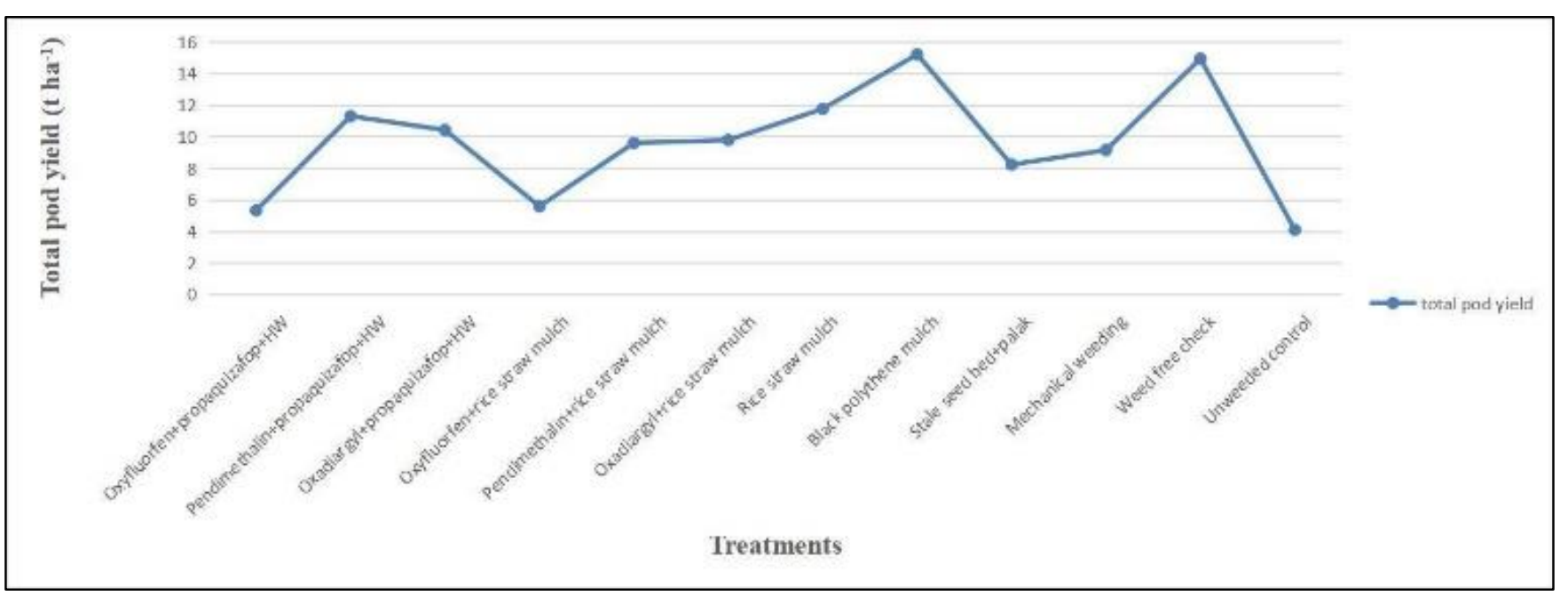

Fig 2: Influence of weed management practices on total pod yield ( $t$ ha-1)

3999 


\section{Conclusion}

The study concluded that black polythene mulch enhanced better plant growth which facilitated in accumulation of more photosynthates and conservation of optimum temperature resulting in increased size and weight which further improved the yield. Higher values were recorded with black polythene sheet mulch and it was followed by weed free check. Plant height, leaf area, no of branches, no of nodes on main stem per plant and the crop dry matter production were the highest in black polythene sheet mulch and it was on par with weed free check. Days to initial and 50 per cent flowering was advanced significantly by 2-4 days in unweeded control due to heavy weed infestation over the other treatments. The yields were inversely related to weed infestation. The highest yield (15.20 t ha-1) was obtained with black polythene sheet mulch which was on par with weed free check (14.93 t ha-1). Due to heavy weed infestation in unweeded control recorded very low yield of $4.09 \mathrm{t}$ ha- 1

\section{Acknowledgments}

Authors want to thank to authorities of Department of Horticulture, Agronomy and Soil Science of universities S.K.L.T.S.H.U and P.J.T.S.A.U, Rajendranagar, Hyderabad

\section{References}

1. Ashish P, Tiwari KN. Evapo transpiration and crop coefficient of okra under subsurface drip with and without plastic mulch. Current Science. 2018; 115:12.

2. Bagudo HA, Dadari SA, Aliyu U. Evaluation of preemergence herbicides for weed control in okra [Abelmoschus esculentus (L.) Moench] in the rima river valley, Sokoto, Nigeria. African Journal of Agricultural Science and Technology. 2016; 4(6):787-793.

3. Bhatt L, Rana R, Uniyal SP, Singh VP. Effect of mulch materials on vegetable characters, yield and economics of summer squash (Cucurbita pepo) under rainfed mid-hill condition of Utharkhand. Vegetable Science. 2011; 38(2):165-168.

4. Bhutia TL, Singh SH, Reddy KCS. Effect of mulching and nitrogen on growth, yield and economics of okra [Abelmoschus esculentus (L.) Moench]. Ecology, Environment \& Conservation. 2017; 23(2):826-832.

5. Dalorima LT, Banu A, Kyari Z, Mohammed T. Effects of different mulching materials on growth performance of okra in Maiduguri. International Research Journal of Agricultural Science and Soil Science. 2014; 4(8):145149.

6. Gopalan C, Rama Sastri BV, Balassubramanian SC. Nutritive value of Indian foods. National Institute of Nutrition. ICMR, Hyderabad, India, 1989.

7. Gordon GG, Foshee WG, Reed ST, Brown JE, Vinson EL. The effects of colored plastic mulches and row covers on the growth and yield of okra. Horticultural Technology. 2010; 20(1):224-233.

8. Hamid RR, Farzad H, Ramin R. Effect of coloured plastic mulches on yield of tomato and weed biomass. International Journal of Environmental Science and Development. 2012; 3(3):590-593.

9. Hazarika BN, Ansari S. Effect of integrated nutrient management on growth and yield of banana cv Jahaji. Indian Journal of Horticulture. 2010; 67(2):270-273.

10. Jalendhar G, Chandra SRK, Srinivas A, Manohar Rao A. Effect of integrated weed management practices on growth, yield and it's attributes in okra [Abelmoschus esculentus (L.) Moench] Cv. Arka Anamika.
International Journal of Science and Nature. 2016; 7(1):165-167.

11. Konyeha S, Alatise MO. Evapotranspiration and leaf area index (LAI) of irrigated okra [Abelmoschus esculentus (L.) Moench] in Akure, south- western city of Nigeria. International Journal of Engineering Sciences and Research Technology. 2013; 2(9):2880-2888.

12. Kumar S, Dey P. Effects of different mulches and irrigation methods on root growth, nutrient uptake, wateruse efficiency and yield of strawberry. Scientia Horticulturae. 2011; 127(3):318-324.

13. Law-Ogbomo KE, Osaigbovo AU, Ewansiha SU. Responses of okra [Abelmoschus esculentus (L.) Moench] to various periods of weed interference in a humid tropical environment. International Journal of Agriculture and Rural Development. 2013; 16(1):13681371.

14. Laxmikanth, Mallikarjun, Rubeena T, Kavitha. Effect of colour plastic mulching and different levels of drip irrigation on plant growth parameters of okra [Abelmoschus esculentus (L.) Moench] Crop. Journal of Pharmacognosy and Phytochemistry. 2018, 3184-3188.

15. Mahadeen AY. Effect of polyethylene black plastic mulch on growth and yield of two summer vegetable crops under rainfed conditions under semi- arid region conditions. American Journal of Agricultural Biological Science. 2014; 9(2):202-207.

16. Manju B, Yadav KS, Satish K, Narayan L, Govind S. Effect of integrated weed management in okra. International Journal of Chemical Studies. 2017; 5(4):1103-1106.

17. Nagegowda NS, Senthivel T, Shankar HS, Senthil KM. Effect of precision farming techniques involving fertigation and mulching on growth attributes and seed yield of okra var. Arka Anamika [Abelmoschus esculentus (L.) Moench]. International Journal of Current Microbiology and Applied Sciences. 2019; 8(2):25022507.

18. National Horticultural Board. Indian Horticulture Database, Guargon, New Delhi, 2018-19.

19. Pandey VK, Mishra AC. Weed management technology in okra. In: National Symposium on Abiotic and Biotic stress Management in Vegetable crops. North America, 2013.

20. Parmar HN, Polara ND, Viradiya RR. Effect of mulching material on growth, yield and quality of watermelon (Citrullus lanatus Thunb) Cv. Kiran. Universal Journal of Agricultural Research. 2013; 1(2):30-37.

21. Patel TU, Zinzala MJ, Patel DD, Patel HH, Italiya AP. Weed management influence on weed dynamics and yield of summer lady's finger. Indian Journal of Weed Science. 2017; 49(3):263-265.

22. Ritesh KJ, Ram BN, Abishkar K, Shailesh P, Bhishma RD. Effect of different spacing and mulching on growth and yield of okra [Abelmoschus esculentus (L.) Moench] in Chitwan, Nepal. Journal of Agriculture and Natural Resources. 2018; 1(1):168-178.

23. Sah D, Heisnam P, Pandey AK. Weed management in okra under foot hill conditions of North Eastern Himalayas. Journal of Crop and Weed. 2018; 14(1):201204.

24. Sathya PR, Chinnusamy C, Perumal M, Murali AP. Evaluation of new formulation of oxyfluorfen $(23.5 \%$ EC) for weed control efficacy and bulb yield in onion. American Journal of Plant Science. 2017; 4:890-895. 
25. Shivalingappa S, Eugenia P, Bangi S, Sattigeri U. Effect of herbicides on weed control efficiency and yield attributes in brinjal. Journal of Agriculture and Veternary Science. 2014; 7(6):59-65.

26. Shivaraj S, Balakrishnan $P$, Srinivas RGV, Kavita K, Patil RP. Effect of colour plastic mulching on plant growth parameters of okra [Abelmoschus esculentus (L.) Moench] crop under different levels of drip irrigation. International Journal of Current Microbiology and Applied Sciences. 2018; 7(2): 3440-3447.

27. Suresh KJ, Madhavi M, Thirupathi R, Satyanarayana RG, Manohar R. Integrated weed management practices and their effect on yield and economics of cabbage. Environment \& Ecology. 2014; 32(2A):718-720. 